\title{
GAMTAMOKSLINIS UGDYMAS PRADINĖJE MOKYKLOJE: PROCESAS IR JO GERINIMAS
}

\author{
Vincentas Lamanauskas \\ Vilniaus universitetas, Lietuva \\ El. paštas: vincentas.lamanauskas@sa.vu.lt
}

\author{
Dalia Augienè \\ Šiauliai, Lietuva \\ El. paštas: augiene@gmail.com
}

\section{Jvadas}

Nepaisant to, kad gamtamokslinis ugdymas (GU) pradinėje mokykloje yra integruotas, jis turi būti kokybiškas. Kitaip sakant, pradinès mokyklos moksleiviai turètų gebèti atlikti paprastus stebejjimus ir bandymus, formuluoti išvadas, naudotis paprasčiausiais prietaisais ir instrumentais ir t. t. Suprantama, kad moksleivių gebejjimai ugdomi palaipsniui ir kryptingai, kad jau nuo pirmosios pradinès mokyklos klasės moksleiviai gauna bazines gamtos pažinimo žinias, formuojasi tam tikrus gebejjimus, pagaliau formuojasi savita gamtamokslinė pasaulio samprata. Ir toliau išlieka tie patys universalūs klausimai pvz., Ką šiuolaikinis jaunimas turi žinoti ir mokèti ir kodèl tai svarbu? Kokie veiksmingiausi gamtos mokslų dalykų mokymo būdai skirtinguose mokyklų sistemos lygiuose? Kokių žinių ir gebejjimų reikia mokytojams? Lietuvos pradinèje mokykloje gamtamokslinis ugdymas iš esmès realizuojamas per Pasaulio pažinimo pamokas ir apima du mokinio socializacijai ir ugdymui itin svarbius tikslus: padèti vaikui pažinti gamtą ir jos procesus bei užtikrinti tinkamą (pozityvią) mokinio socializaciją.

Gamtamokslinis ugdymas apima jvairius komponentus - ekologinį, aplinkosaugini, sveikos gyvensenos, darnaus vystymosi ir kt. Itin svarbi eksperimentinè-tiriamoji veikla. Efektyvus visų komponentų integravimas j̇ ugdymo procesą pradinèse klasėse išlieka problematiškas (Lamanauskas \& Augienė, 2018). \vairūs tyrimai akcentuoja, kad pradinès mokyklos mokytojai susiduria su j̇vairiomis problemomis mokydami gamtos mokslų pradiniame lygmenyje. Bendra problema gana aiški - mokiniai nesidomi gamtos mokslais arba toks domejjimasis ganètinai menkas. Kaip teigia tyrèjai, tokios problemos, jei jos nenustatytos, gali turèti j̇takos gamtos mokslų mokymo kokybei aukštesnejje bendrojo ugdymo pakopoje (GarrawayLashley, 2019). Užsienio šalių tyrèjai teigia, kad vis dar mažai žinoma apie mokytojų poziciją (nuomonę) dèl tiriamosios veiklos tikslų, tiriamosios veiklos organizavimo ir vykdymo procesų, pagaliau apie mokytojų motyvaciją atlikti sudètingesnę tiriamąą veiklą (Keys, Bryan, 2001). Akivaizdu, kad motyvacijos didinimas, mokytojų bendradarbiavimo skatinimas, atitinkama parama išlieka svarbiu gamtamokslinio ugdymo gerinimo veiksniu (Watters \& Ginns, 2000). Kita vertus svarbu, kaip pradinių 
klasių mokytojai gali jž̌velgti naujas gamtos mokslų mokymosi galimybes, taip pat adekvačiai suvokti GU potencialą. Anot tyrèjų, būtina ištirti, kaip pradinių klasių mokytojai supranta gamtos mokslus ir gamtos mokslų dalykų mokymą. Tokiu būdu galima būtų aiškiai nustatyti, kokie gamtos mokslų aspektai yra svarbūs pradinės mokyklos lygmenyje ir kaip jie gali virsti atitinkamomis mokymo(si) patirtimis (Fitzgerald \& Smith, 2016). Išlieka ir problema, kuomet pradinių klasių mokytojai nèra tinkamai pasirengę gamtamokslinio ugdymo srityje. Tyrimai rodo, kad daugelis pradinių klasių mokytojų vengia dèstyti gamtos mokslų dalykus, neišmano gamtos mokslų ir jiems neretai trūksta pasitikèjimo mokant gamtos dalykų (Mellado ir kt., 1998; Smith \& Neale, 1989).

2018 metais atliktame pilotiniame tyrime nustatyta, kad pradinių klasių mokytojų profesinis pasirengimas gamtamokslinio ugdymo srityje išlieka aktualus. Nors mokytojai yra linkę demonstruoti jvairius eksperimentus, tyrinejjimo veikla nèra vyraujanti. Panaši padėtis stebima ir kalbant apie technologijų panaudojimą ugdymo procese. Mokytojų pasirengimas organizuoti ir realizuoti gamtamokslini ugdymą pradinèje mokykloje yra gana nevienodas (Lamanauskas, 2018).

Taigi, pagrindinis šio tyrimo tikslas - išanalizuoti pradinių klasių mokytojų poziciją gamtamokslinio ugdymo klausimu, t. y. nustatyti, kokius jžvelgia gamtamokslinio ugdymo gerinimo būdus, bei kokie veikos būdai gamtamokslinio ugdymo procese labiausiai (pa)tinka, kaip vykdoma tiriamoji veikla GU procese. Šis tyrimas grindžiamas anksčiau atliktu pilotiniu tyrimu ir ji papildo bei praplečia.

\section{Tyrimo metodologija}

\section{Bendra tyrimo charakteristika}

Atliktas kiekybinis tyrimas taikant apklausos strategiją. Apklausa dažnai taikoma, kai tiriamas reiškinys yra susijęs su žmonių nuostatomis, poreikiais, interesais, motyvacija ir pan. Apklausos tyrimas yra naudingas siekiant suprasti tiriamujjų mintis, idèjas, nuomones ir požiūrį. Toks tyrimas yra aprašomojo pobūdžio, todèl skirtingai nei eksperimentiniai tyrimai, tyrèjas kintamaisiais nemanipuliuoja (Burns \& Grove, 2005). Socioedukaciniuose tyrimuose apklausa taikoma kaip instrumentas informacijai iš respondentų surinkti iš anksto apgalvotais klausimais. Tyrimas atliktas 2021 metų vasario-balandžio mènesiais.

\section{Tiriamieji}

Tyrime dalyvavo dirbantys pradinių klasių mokytojai iš jivairių Lietuvos pradinių mokyklų. Iš viso dalyvavo 115 mokytojų iš daugiau nei 30 Lietuvos mokyklų. Visi tiriamieji pagal lyti - moterys. Tyrimo imti iš esmès galima laikyti tinkama. Kadangi tyrime analizuojama nedaug kintamujuç, todèl esant santykinai nedideliam kintamųjų skaičiui bei homogeniškai populiacijai galima mažesnè imtis pagal tūrị (Neuman, 1997). Taigi, laikomasi nuostatos, kad tokia imtis yra ganètinai reprezentatyvi kiekybiniame, ribotos apimties tyrime. 


\section{Instrumentas}

Tyrimo instrumentas anketa, sudaryta iš 6 klausimų. Keturių klausimų atveju yra galimybè respondentams pateikti komentarus ir pastabas. I tyrimo instrumentą yra jitraukti klausimai, jau taikyti ankstesniame tyrime (Lamanauskas, 2018). Tai pirmasis, antrasis ir trečiasis klausimai. Jie iš dalies modifikuoti ir papildyti atsižvelgiant i ankstesnio tyrimo patirtį. Taikomos nominalinès ir intervalinès bei ranginès skalès (priedas Nr. 1). Pirminis tyrimo instrumento validavimas atliktas 2018 metais pilotinio tyrimo metu.

Po kai kurių anketos klausimų buvo pateikti atvirieji klausimai, siekiant sulaukti mokytojų praktikų pastabų ir komentarų. Šiame straipsnyje pristatomi rezultatai susiję su gamtamokslinio ugdymo būdais, proceso gerinimu ir su mokiniais atliekama tiriamąja veikla (pilnas tyrimo instrumentas pateikiamas Priede).

\section{Duomeny̨ analizé}

Duomenys išanalizuoti taikant pagrindinius aprašomosios statistikos matus. Skaičiuoti absoliutiniai ir santykiniai dažniai, aritmetinis vidurkis ir standartine paklaida (SD). Vertinant tiriamosios veiklos organizavimą ir vykdymą Pasaulio pažinimo pamokose, skaičiuotas reikšmingumo indeksas $\mathrm{RI}(0 \leq \mathrm{RI} \leq 1)$. Kuo RI vertè arčiau 1, tuo veiklos vykdymas yra dažniau taikomas / realizuojamas. Empiriniai duomenys apdoroti taikant statistinio duomenų apdorojimo paketą SPSS (24 vers.).

\section{Tyrimo rezultatai}

Išanalizuota kokius gamtamokslinio ugdymo būdus mokytojai taiko dažniausiai Pasaulio pažinimo pamokose (1 lentelè).

\section{1 lentelè}

Dažniausiai taikomi gamtamokslinio ugdymo būdai

\begin{tabular}{lcc}
\hline \multicolumn{1}{c}{ Būdai } & N & \% \\
\hline Itraukti (organizuoti) praktinĭ darbą (veiklą) & 66 & 23,4 \\
\hline Demonstruoti eksperimentus & 52 & 17.8 \\
\hline Susieti gamtamokslini turini su kasdieniu mokinių gyvenimu & 44 & 15,0 \\
\hline Itraukti (organizuoti) grupini darbą & 42 & 14,4 \\
\hline Skatinti klasės diskusijas & 32 & 10,2 \\
\hline Leisti mokiniams atlikti savarankiškus tyrinejjimus (eksperimentus) & 23 & 7,8 \\
\hline Naudoti technologijas & 14 & 4,8 \\
\hline Skatinti (palengvinti) tyrinejjimą & 12 & 4,2 \\
\hline Patenkinti (atsižvelgti) individualius skirtumus & 7 & 2,4 \\
\hline
\end{tabular}

*iš viso 292 pasirinkimai 
Kaip matyti 1-oje lentelèje, vieni dažniausiai mokytojų taikomų būdų yra siekis j̇traukti mokinius i praktinę veiklą $(23,4 \%)$ bei demonstruoti eksperimentus (17,8 \%). Tuo tarpu jivairių technologijų panaudojimas, savarankiškas tyrinèjimas yra mažiausiai taikomi būdai. Tokią poziciją atspindi ir tiriamųjų komentarai. Pateikiame būdingesnius:

„Vaikai labai aktyviai jsijungia j veiklq. Jiems labai jdomu ir noriai atlieka užduotis" (respondentas A).

„... ugdo socialines kompetencijas: savimonę, savitvardq, tarpusavio santykius; svarbu tenkinti natūraly vaiku poreiki judeti, plètoti dvasinius ir fizinius gebejjimus, puoselèti mokinių sveikatingumq ir sveikq gyvensenq, ekologinę kultūrq" " (respondentas $\mathrm{B}$ ).

"Stengiuosi kiek jmanomq pamokq pajvairinti praktiniu darbu, tyrinèjimu, eksperimentu, papildoma medžiaga iš temos" (respondentas C).

„Šie būdai lavina kūrybini mąstymą, mokiniai išsiugdo siekimq nuolat mokytis, gebejjimq rinkti informacijq, jq analizuoti, kritiškai vertinti, pritaikyti praktikoje" (respondentas D).

"Tokios pamokos labai smagios. Tik neimanoma skirti pakankamai tam laiko. Programy apimtis labai didelè. Suderinti teorinę medžiagq ir praktinę veiklą, neįmanoma. O didelès klasès klasès to neleidžia. Kai dirbi su 10 mokinių visai kitaip" (respondentas E).

"Stengiuosi naudoti papildomq literatūrq, interneta, kiek leidžia galimybès rodyti, eksperimentuoti pamoky metu.Visa tai darau, kad mokiniams būtų kuo ¡domiau ir geriau jsiminty pamokos medžiagq" (respondentas F).

Akivaizdu, kad tiriamoji veikla itin svarbi pradinio gamtamokslinio ugdymo procese. Respondentai akcentuoja tiriamosios veiklos reikšmę. Išanalizuota kaip dažnai mokytojai su mokiniais vykdo tyrimus (tiriamąją veiklą) Pasaulio pažinimo pamoku metu pagal pagrindines gamtamokslinio ugdymo sritis. Rezultatai pateikiami 2 lenteleje. 


\section{2 lentelè}

Mokinių atliekami tyrimai (tiriamoji veikla) Pasaulio pažinimo pamokose

\begin{tabular}{|c|c|c|c|c|}
\hline GU sritys & $N$ & $x$ & $S N$ & $R \boldsymbol{I}$ \\
\hline Sveika gyvensena & 115 & 3,42 & 0,94 & 0,60 \\
\hline Aplinkos apsauga & 115 & 2,93 & 0,85 & 0,48 \\
\hline Ekologija & 115 & 2,85 & 1,00 & 0,46 \\
\hline Meteorologija & 115 & 2,65 & 0,89 & 0,41 \\
\hline Augalija (flora) & 115 & 2,64 & 0,66 & 0,41 \\
\hline Gyvūnija (fauna) & 115 & 2,44 & 0,78 & 0,36 \\
\hline Fizikiniai reiškiniai & 115 & 2,38 & 0,76 & 0,35 \\
\hline Žemès ūkis / žemdirbystė & 115 & 2,35 & 0,78 & 0,33 \\
\hline Cheminių medžiagų j̇taka augalams ir gyvūnams & 115 & 2,11 & 0,72 & 0,28 \\
\hline Dirvožemis, mineralai ir uolienos & 115 & 2,09 & 0,69 & 0,27 \\
\hline
\end{tabular}

Antroje lentelejje matyti, kad tiriamoji veikla labiausiai susijusi su trimis sritimis - sveika gyvensena, aplinkos apsauga ir ekologija. Galima teigti, kad tokiose srityse: kaip fizikiniai reiškiniai (fizika), cheminiai reiškiniai (chemija) ir gyvosios gamtos reiškiniai (biologija), tiriamoji veikla yra menkai vykdoma arba išvis nevykdoma. Galima manyti, kad pirmosios trys sritys yra integralios, joms daugiau dèmesio skiriama ir ugdymo programoje, mokytojams labiau suprantamos, ir todèl tiriamoji veikla čia yra dažnesnè.

"Tiriamajq veiklq atliekame pagal ugdymo turinio temas, ne visos čia išvardytos sritys įtrauktos i pamoky planus pradinése klasése. Yra skiriama vos viena pamoka temai perteikti, todèl negalime tyrimo tęsti kiekvienq pamokq. Nebent tai būtu atliekama būrelio ar modulio metu" (respondentas A).

„Tyrimai būna ilgalaikiai. Pvz., visq savaitę 3 kartus dienoje stebèti temperatūros skirtumus" (respondentas B).

"Tyrimai atliekami atsižvelgiant j ugdymo turinj, mokyklos mety temq (pvz., žemé, oras, vanduo...) vykdomq projektinę veiklq ir t. t." (Respondentas C).

"Sunku atsakyti kaip dažnai, jeigu tuo metu mokomés istorinių temų, tai ty tyrimy ir nevykdome. Pvz., 4 klasèje pagrinde mokomés istorijos. Pvz., "Naudingos iškasenos" - 1 pamoka. Tai tq pamokq ir mokomés atpažinti, pačiupinèti, dar tiriame molio savybes, integruojame su technologijomis (dirbiniai iš molio)" (respondentas D). 
Taip pat išanalizuota respondentų pozicija apie galimybes pagerinti gamtamokslini ugdymą pradinèje mokykloje. Rezultatai pateikiami 3 lentelèje.

\section{3 lentelè}

Gamtamokslinio ugdymo gerinimo būdai pradinèje mokykloje

\begin{tabular}{|c|c|c|}
\hline Gerinimo būdai & $N$ & $\%$ \\
\hline Turèti daugiau išteklių / j̨rangos ir pan. & 52 & 25,2 \\
\hline Itraukiant daugiau praktinio darbo (veiklos) & 26 & 12,6 \\
\hline Stengtis gamtamokslinį turini padaryti artimesniu mokinių kasdieniam gyvenimui & 22 & 10,9 \\
\hline Vesti pamokas labiau orientuotas i mokinj & 21 & 10,2 \\
\hline Turèti geresnę prieigą prie technologijų ir jų naudojimo & 18 & 8,7 \\
\hline Turėti mažesnes klases (mažiau mokinių) & 16 & 7,8 \\
\hline Turèti daugiau laiko gamtamokslinio turinio parinkimui, analizei ir t. t. & 14 & 6,8 \\
\hline Turèti daugiau laiko pasirengti pamokai (-oms) & 12 & 5,8 \\
\hline Turèti daugiau galimybių mokytojo profesiniam tobulèjimui & 9 & 4,4 \\
\hline ltraukiant daugiau grupinio darbo/veiklos & 8 & 3,8 \\
\hline Itraukti (organizuoti) daugiau tyrinèjimu grįstų pamokų & 8 & 3,8 \\
\hline Viso & 206 & 100,0 \\
\hline
\end{tabular}

3-ioje lentelèje matyti, kad kaip vienas esminių būdų nurodomas poreikis ištekliams / įrangai, t. y. materialiniams resursams (25,2 \%). Taip pat išskiriama pozicija įtraukti daugiau praktinio darbo (veiklų) (12,6 \%), labiau sieti GU procesą su kasdieniu mokinių gyvenimu (10,9\%), bei didinti orientaciją i mokini (10,2 \%). Dalis mokytojų teigia, kad gamtamokslinio ugdymo kokybé gerètų, jei jie turètų daugiau laiko gamtamokslinio turinio parinkimui, analizei ir t. t. (6,8\%), pasirengti pamokoms $(5,8 \%)$, turètų daugiau galimybių profesiniam tobulèjimui $(4,4 \%)$. Deja, daugiau tyrinèjimu grįstų pamokų organizavimas (jtraukimas i GU procesą) nelaikomas reikšmingu GU gerinimo būdu (3,8\%). Tas pats pasakytina ir apie mokinių grupinès veiklos organizavimą (3,8\%).

\section{Išvados}

Mokytojai gamtamoksliniame vaikų ugdyme naudoja j̨vairius būdus. Dažniausiai naudojamas yra mokinių jtraukimas i praktini darbą (veiklą), eksperimentų demonstravimas, stengiamasi susieti gamtamokslinį turini su kasdieniu mokinių gyvenimu, organizuoti grupini mokinių darbą. Gerokai rečiau skatinamos klasės diskusijos bei leidžiama mokiniams atlikti savarankiškus tyrinėjimus (eksperimentus). Retai siekiama j̇traukti technologijas, skatinti (palengvinti) tyrinėjimą, patenkinti (atsižvelgti) individualius mokinių skirtumus. 
Pradinio gamtamokslinio ugdymo procese su mokiniais dažniausiai atliekami tyrimai susiję su sveika gyvensena, aplinkos apsauga, ekologija. Rečiau mokiniai atlieka augalijos (floros), gyvūnijos (faunos), fizikinių reiškinių tyrimus. Labai retai mokiniai atlieka tyrimus susijusius su žemės ūkiu / žemdirbyste, cheminių medžiagų j̇taka augalams ir gyvūnams. Ypač retai mokiniai tyrinèja dirvožemį, mineralus ir uolienas.

Mokytojai teigia, kad gamtamokslinį ugdymą pradinèje mokykloje galima būtų pagerinti turint daugiau išteklių / ịrangos ir pan., j̇traukiant daugiau praktinio darbo (veiklos), stengiantis gamtamokslinį turini padaryti artimesniu mokinių kasdieniam gyvenimui, vedant pamokas labiau orientuotas į mokinį, turint geresnę prieigą prie technologijų ir jų naudojimo, mažinant mokinių skaičių klasėse. Dalis mokytojų nurodo, kad svarbu daugiau laiko skirti gamtamokslinio turinio parinkimui, analizei ir t. t., pamokų pasirengimui, turèti daugiau galimybių mokytojo profesiniam tobulèjimui.

\section{Literatūra}

Burns, N., \& Grove, S. K. (2005). The practice of nursing research: Conduct, critique, and utilization (5th ed.). Elsevier.

Fitzgerald, A., \& Smith, K. (2016). Science that matters: Exploring science learning and teaching in primary schools. Australian Journal of Teacher Education, 41(4), 63-78. https://files.eric.ed.gov/fulltext/EJ1098113.pdf

Garraway-Lashley, Y. M. (2019). Teaching science at the primary school level: "Problems teachers' are facing". Asian Journal of Education and E-Learning, 7(3), 81-94. https://doi.org/10.24203/ajeel.v7i3.5847

Keys, C. W., \& Bryan, L. A. (2001). Co-constructing inquiry-based science with teachers: Essential research for lasting reform. Journal of Research in Science Teaching, 38(6), 631-645.

Lamanauskas, V. (2018). Gamtamokslinio ugdymo procesas pradinèje mokykloje: organizavimo ir gerinimo aspektai [Natural science education process in primary school: Organisation and improvement aspects]. Gamtamokslinis ugdymas bendrojo ugdymo mokykloje - 2018 / Natural Science Education in a Comprehensive School, 24, 24-32. https://oaji.net/articles/2017/1984-1523816483.pdf

Lamanauskas, V., Augienè, D. (2018). Scientific research activity organisation and improvement in a primary school. Review of Science, Mathematics and ICT Education, 12(2), 5-20. https://doi.org/10.26220/rev.2938

Mellado, V., Blanco, L. J., \& Ruiz, C. (1998). A framework for learning to teach science in initial primary teacher education. Journal of Science Teacher Education, 9, 195-219. https://www.jstor.org/stable/43156195

Neuman, W. L. (1997). Social research methods: Qualitative and quantitative approaches (3rd ed.). Allyn and Bacon.

Smith, D. C., \& Neale, D. C., (1989). The construction of subject matter knowledge in primary science teaching. Teaching and Teacher Education, 5(1), 1-20. https://doi.org/10.1016/0742-051X(89)90015-2 
Watters J. J., \& Ginns, I. S. (2000). Developing motivation to teach elementary science: Effect of collaborative and authentic learning practices in preservice education. Journal of Science Teacher Education, 11(4), 301321. https://doi.org/10.1023/A:1009429131064

\section{Priedas}

Tyrimo instrumentas

GAMTAMOKSLINIS UGDYMAS PRADINĖJE MOKYKLOJE

\section{Mielas (-a) kolega (-e),}

Tyrèjų grupè vykdo tyrimus, susijusius su gamtamokslinio ugdymo tobulinimu pradineje mokykloje.

Pagrindinis šio tyrimo tikslas - išanalizuoti pradinių klasių mokytojų poziciją gamtamokslinio ugdymo klausimu. Tikimès, jūsų išsamių, atvirų ir nuoširdžių atsakymų i keletą klausimų.

1. Gamtamokslinio ugdymo procese pradinèje mokykloje (pvz., Pasaulio pažinimo pamokose) man išties patinka (aš stengiuosi) /pažymèkite labiausiai tinkantį (čius) būdą (us) x:

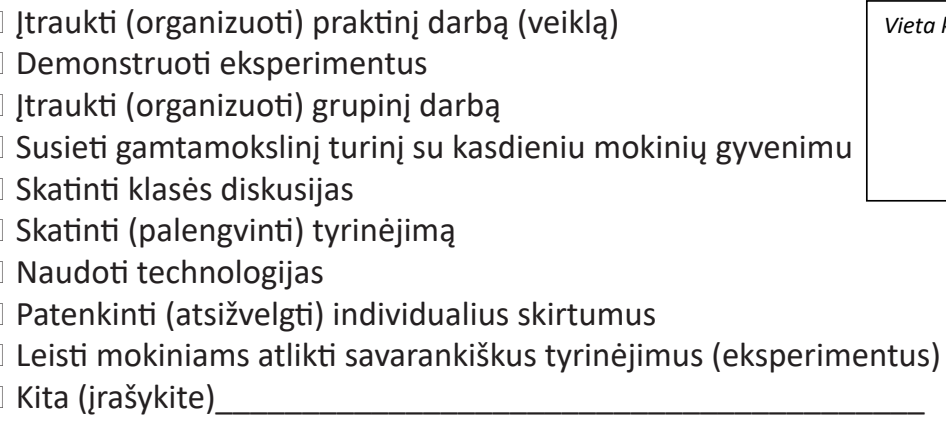

2. Ivertinkite savo pasirengimą organizuoti ir realizuoti gamtamokslinį ugdymą pradinèje mokykloje (pvz., mokyti pasaulio pažinimo ir kt.)? Pažymékite tik vienq langeli kiekvienai sričiai $\boldsymbol{X}$

1 - Aš jaučiuosi labai gerai pasirengusi (ęs) mokyti šiq mokslo sritị savo turimomis žiniomis ir jigūdžiais

2 - Aš jaučiuosi pakankamai gerai pasirengusi (ęs) mokyti šiq mokslo sriț, žinodamas, kad galiu visada remtis kolegu pagalba

3 - Manau, kad su papildoma pagalba man, esu pakankamai pasirengusi (ęs) mokyti šiq mokslo sritj

4 - Aš nejaučiu pakankamai pasiruošusi (ęs) mokyti šiq mokslo sriti ir todèl man reikia esminés pagalbos 
5 - Aš pripažistu, kad tai yra mano silpniausia mokslo sritis ir, kad net esant esminei paramai man reiks nemažai laiko, kol aš kada nors jausiuosi pilnai pasiruošusi (ęs).

\begin{tabular}{|l|l|l|l|l|l|}
\hline \multicolumn{1}{|c|}{ Sritis } & $\mathbf{1}$ & $\mathbf{2}$ & $\mathbf{3}$ & $\mathbf{4}$ & $\mathbf{5}$ \\
\hline Mokslinis tyrimas (tyrinėjimas) & & & & & \\
\hline Gyvybės (gyvybiniai) procesai & & & & & \\
\hline Žmonės ir kiti gyvūnai & & & & & \\
\hline Sveika gyvensena (Žmogaus sauga ir sveikata) & & & & & \\
\hline Žalieji augalai & & & & & \\
\hline Gyvosios ir negyvosios gamtos jvairovė ir klasifikacija & & & & & \\
\hline Gyvieji organizmai ir jų aplinka & & & & & \\
\hline Medžiagų grupavimas ir klasifikavimas & & & & & \\
\hline Medžiagų kitimai & & & & & \\
\hline Medžiagų mišinių atskyrimas & & & & & \\
\hline Elektra (elektriniai reiškiniai) & & & & & \\
\hline Jėgos ir judèjimas & & & & & \\
\hline Šviesa ir garsas & & & & & \\
\hline Globalinė klimato kaita & & & & & \\
\hline Aplinkos apsauga & & & & & \\
\hline Žemės planeta ir Visata & & & & & \\
\hline
\end{tabular}

3. Gamtamokslinį ugdymą pradinèje mokykloje (pvz., Pasaulio pažinimą) galima būtų pagerinti (pažymékite X labiausiai jums tinkančius)

$\square$ Vesti pamokas labiau orientuotas į mokini

$\square$ Turèti daugiau išteklių /įrangos ir pan.

$\square$ ltraukiant daugiau grupinio darbo

$\square$ Turèti geresnę prieigą prie technologijų ir

jų naudojimo

$\square$ Itraukiant daugiau praktinio darbo (veiklos)

Vieta komentarui:

Turèti daugiau laiko gamtamokslinio turinio parinkimui, analizei ir t. t.

Turèti mažesnes klases (mažiau mokinių)

$\square$ lıtraukti (organizuoti) daugiau tyrinèjimu gristų pamokų 
Turèti daugiau laiko pasirengti pamokai (-oms)

Turèti daugiau galimybių mokytojo profesiniam tobulejimui

Stengtis gamtamokslinį turinį padaryti artimesniu mokinių kasdieniam gyvenimui

Kita (jrašykite)

\section{Kaip dažnai vykdote tyrimus (tiriamąą veiklą) per savo pasaulio pažinimo pamokas} šiose srityse?

\begin{tabular}{|c|c|c|c|c|c|}
\hline Sritys & $\begin{array}{c}1 \\
\text { Niekada }\end{array}$ & $\begin{array}{c}2 \\
\text { Maždaug } \\
\text { kartq per } \\
\text { semestrq } \\
\text { ar mažiau }\end{array}$ & $\begin{array}{c}3 \\
\text { Maždaug } \\
\text { kartq per } \\
\text { ménesj }\end{array}$ & $\begin{array}{c}\mathbf{4} \\
\text { Maždaug } \\
\text { kartq per } \\
\text { savaitę }\end{array}$ & $\begin{array}{c}5 \\
\text { Beveik }\end{array}$ \\
\hline \multicolumn{6}{|l|}{ Augalija (flora) } \\
\hline \multicolumn{6}{|l|}{ Gyvūnija (fauna) } \\
\hline \multicolumn{6}{|l|}{ Meteorologija } \\
\hline \multicolumn{6}{|l|}{$\begin{array}{l}\text { Cheminiu medžiagu i itaka } \\
\text { augalams ir gyvūnams }\end{array}$} \\
\hline \multicolumn{6}{|l|}{ Fizikiniai reiškiniai } \\
\hline \multicolumn{6}{|l|}{ Aplinkos apsauga } \\
\hline \multicolumn{6}{|l|}{ Sveika gyvensena } \\
\hline \multicolumn{6}{|l|}{ Ekologija } \\
\hline \multicolumn{6}{|l|}{ Žemės ūkis / žemdirbystè } \\
\hline \multicolumn{6}{|l|}{ Dirvožemis, mineralai ir uolienos } \\
\hline Komentarai: & & & & & \\
\hline
\end{tabular}

5. Koks yra pagrindinis jūsų informacijos šaltinis gamtamokslinio ugdymo srityje?/ suranguokite nuo 1 iki 10, kur 1 yra šaltinis, kuri naudojate daugiausia, o 10 šaltinis, kuri naudojate mažiausiai - naudokite kiekvienq numeri tik vienq kartq/.

\begin{tabular}{|l|l|l|l|}
\hline No. & \multicolumn{1}{|c|}{ Šaltinis } & \multicolumn{1}{c|}{ Rangas } & \multicolumn{1}{c|}{ Netaikoma } \\
\hline 1 & Internetas & $\square$ & $\square$ \\
\hline 2 & Knygos & $\square$ & $\square$ \\
\hline 3 & Žurnalai & $\square$ & $\square$ \\
\hline 4 & Laikraščiai & $\square$ & $\square$ \\
\hline 5 & Televizija & $\square$ & $\square$ \\
\hline 6 & Kinas/filmai & $\square$ & $\square$ \\
\hline 7 & Radijas & $\square$ & $\square$ \\
\hline 8 & Kolegos & $\square$ & $\square$ \\
\hline 9 & Šeima ir draugai & $\square$ & $\square$ \\
\hline 10 & Ekspertai & $\square$ & $\square$ \\
\hline
\end{tabular}


6. Ivertinkite kaip susipažinęs (-usi) esate su šiomis temomis/sritimis? /pažymèkite atitinkamame langelyje/.

\begin{tabular}{|l|l|l|l|l|l|}
\hline \multicolumn{1}{|c|}{ Sritys } & $\begin{array}{c}\text { Visiškai ne- } \\
\text { susipažinusi }\end{array}$ & $\begin{array}{c}\text { Šiek tiek } \\
\text { susipaži- } \\
\text { nusi }\end{array}$ & $\begin{array}{c}\text { Gerai susi- } \\
\text { pažinusi }\end{array}$ & $\begin{array}{c}\text { Pakan- } \\
\text { kamai } \\
\text { susipaži- } \\
\text { nusi kad to } \\
\text { mokyti }\end{array}$ & $\begin{array}{c}\text { Pakankamai } \\
\text { susipažinusi, } \\
\text { tad galěčiau tai } \\
\text { aptarti su eks- } \\
\text { pertais }\end{array}$ \\
\hline $\begin{array}{l}\text { Nauji mokslo atra- } \\
\text { dimai }\end{array}$ & & & & & \\
\hline $\begin{array}{l}\text { Nauji išradimai ir } \\
\text { technologijos }\end{array}$ & & & & & \\
\hline $\begin{array}{l}\text { Kosmoso tyrineji- } \\
\text { mas }\end{array}$ & & & & & \\
\hline $\begin{array}{l}\text { Genu technologija } \\
\text { (inžinerija) }\end{array}$ & & & & & \\
\hline Nanotechnologijos & & & & & \\
\hline Globalinis atšilimas & & & & & \\
\hline $\begin{array}{l}\text { Nauji medicinos at- } \\
\text { radimai }\end{array}$ & & & & & \\
\hline $\begin{array}{l}\text { Aplinkosaugos klau- } \\
\text { simai }\end{array}$ & & & & & \\
\hline Komentarai & & & & \\
\hline
\end{tabular}

Komentarai:

Dékojame už nuoširdžius atsakymus ir linkime Jums sékmés!

\section{Summary}

NATURALSCIENCE EDUCATION IN PRIMARY SCHOOL: THE PROCESS AND ITS IMPROVEMENT

Vincentas Lamanauskas

Vilnius University, Lithuania

\section{Dalia Augienè}

Šiauliai, Lithuania

Despite the fact that science education (SE) in primary school is integrated, it must be of high quality. In other words, primary school students should be able to perform simple observations and tests, formulate conclusions, use the simplest devices and instruments, and so on.

The same universal questions remain, such as What do young people need to know and understand? why is it important? What are the most effective ways of teaching science at different levels of the school system? What knowledge and skills do teachers need? In Lithuanian primary school (1-4 grades), science education is mainly implemented through World Cognition lessons and includes two goals that are very important for the student's socialization and education: to help the child get to know nature and its processes and to ensure appropriate (positive) student socialization. 
Although teachers tend to demonstrate a variety of experiments, student research activities are not predominant. A similar situation is observed with regard to the use of technology in the educational process. The readiness of teachers to organize and implement science education in primary school is quite uneven/diverse.

Thus, the main aim of this study was to analyse the position of primary school teachers on the issue of science education, i.e., to determine which ways of improving science education one sees, and which methods of activity in the process of science education are most appropriate, how student research activities are carried out in the SE process.

A quantitative study using a survey strategy was conducted. In-service primary school teachers from various Lithuanian primary schools participated in the study. A total of 115 teachers from more than 30 Lithuanian schools participated.

Teachers use a variety of methods in their science education. The most frequently used are the involvement of students in practical work (activities), demonstration of experiments, attempts to link science content with the daily life of students, to organize group work of students. Class discussions are much less often encouraged, and students are allowed to carry out independent research (experiments). The aim is rarely to incorporate technology, to encourage (facilitate) research, to meet (take into account) the individual differences of students.

In the process of primary science education, the most common research with students is related to a healthy lifestyle, environmental protection, and ecology. Less often, students do research on vegetation (flora), fauna (fauna), physical phenomena. Very rarely students do research on agriculture / the effects of chemicals on plants and animals. Students rarely explore soil, minerals, and rocks.

Teachers argue that science education in primary school could be improved with more resources / equipment, etc., by including more practical work (activities) in an effort to bring science content closer to students' daily lives, with more student-centred lessons, better access to technology and their use in reducing the number of students in the classroom. Some teachers point out that it is important to devote more time to the selection and analysis of science content, etc., to the preparation of lessons and to have more opportunities for the professional development of teachers.

Keywords: professional development, primary school, practical activities, science education

Cite as: Lamanauskas, V., \& Augienè, D. (2021). Gamtamokslinis ugdymas pradinèje mokykloje: procesas ir jo gerinimas [Natural science education in primary school: The process and its improvement]. Gamtamokslinis ugdymas bendrojo ugdymo mokykloje / Natural Science Education in a Comprehensive School, 27, 24-35. https://doi.org/10.48127/gu/21.27.24 